\section{Nitrogen Sources for Organic Vegetable Crops}

\author{
Mark Gaskell ${ }^{1,3}$ and Richard Smith ${ }^{2}$
}

\begin{abstract}
AdDITIONAL INDEX wORDS. sustainable agriculture, fertilizers, compost,
\end{abstract} green manure crops

\begin{abstract}
SumMARY. Fertilization is the most expensive cultural practice for the increasing numbers of organic vegetable growers in the United States. Nitrogen $(N)$ is the most important and costly nutrient to manage, and cost-effective $\mathrm{N}$ management practices are needed for efficient organic vegetable production. There is a wide array of organic $\mathbf{N}$ sources available, but they vary in cost, $\mathbf{N}$ content, and $\mathbf{N}$ availability. Compost and cover crops are commonly used sources of $\mathrm{N}$ for vegetables because they are relatively inexpensive and offer additional nutrients or soil improvement qualities in addition to $\mathrm{N}$. Studies have shown that compost quality factors that affect $\mathrm{N}$ mineralization vary by source and among different batches from the same source. Compost carbon to $\mathrm{N}$ ratio should be equal to or less than 20:1 to assure net short-term mineralization. Cover crops also vary in $\mathrm{N}$ content and mineralization rate after incorporation. Leguminous cover crops decompose and release $\mathbf{N}$ more rapidly than grass or cereal cover crops at the preheading stage typically incorporated. Even the most efficient N-supplying composts, cover crops, or other organic $\mathrm{N}$ sources do not release appreciable $\mathrm{N}$ to a subsequent crop beyond 6 to 8 weeks from incorporation, and this burst of early $\mathrm{N}$ may not synchronize with $\mathrm{N}$ requirements for many vegetable crops. Other potential organic fertilizer $\mathrm{N}$ sources have been evaluated for vegetables, and they vary in $\mathbf{N}$ cost and $\mathbf{N}$ mineralization rate. Materials evaluated include seabird guano, liquid fish, feather meal, corn meal (Zea mays), blood meal, and liquid soybean meal (Glycine max) among others. Of those evaluated, feather meal, seabird guano, and liquid fish stand out as more economical organic sources of available N. Organic sources generally lack uniformity and are bulky, unstable, and inconsistent as a group, and this contributes to additional hidden management costs for organic growers. Liquid organic $\mathrm{N}$ sources for use in microirrigation systems may have additional disadvantages caused by loss of valuable nutrient $\mathrm{N}$ that is removed by filters.
\end{abstract}

S oil fertility management is an important and costly cultural practice for organic vegetable growers. Nitrogen $(\mathrm{N})$ is often the most limiting nutrient to efficient and profitable vegetable production and at the same time, $\mathrm{N}$ losses and inefficient $\mathrm{N}$ management have the potential for contaminating water bodies adjoining farmland. Organic growers are limited to organic sources of $\mathrm{N}$ or those derived from natural processes. Soil organic matter (SOM) is the backbone of $\mathrm{N}$ supply in organic production, and cultural practices to manipulate $\mathrm{N}$ start with building SOM. Other important potential sources of $\mathrm{N}$ include fixed $\mathrm{N}$ from legumes included as a cover or rotation crop, compost produced from on-farm or off-farm materials, manures from on-farm or off-farm

${ }^{1}$ Farm Advisor, University of California Cooperative Extension, 624 West Foster Road, Santa Maria, CA 93455

${ }^{2}$ Farm Advisor, University of California Cooperative Extension, 1432 Abbott Street, Salinas, CA 93901

${ }^{3}$ Corresponding author. E-mail: mlgaskell@ucdavis.edu. sources, and purchased organic fertilizers.

When discussing organic $\mathrm{N}$ fertility programs, it is important to distinguish between short-term and long-term effects. Studies have shown that the total supply of $\mathrm{N}$ from SOM on organic farms may be in excess of crop needs but that the timing of $\mathrm{N}$ availability is often a critical limitation (Berry et al., 2002). The relatively low and uncertain $\mathrm{N}$ availability of organic nutrient sources as a group in combination with how they are used determine the short-term nutrient value of a material. All of the added organic materials contribute to SOM pools and affect long-term nutrient status of the soil. Although the addition of organic nutrient sources creates shortand long-term nutritional effects as well as an overall beneficial effect on soil structure and related properties, this discussion is limited to direct effects on the $\mathrm{N}$ nutrition of an organic vegetable crop. This review discusses the $\mathrm{N}$ sources and the factors affecting $\mathrm{N}$ fertility management for organic vegetable production.

\section{Mineralization of organic matter}

The potential sources of $\mathrm{N}$ in organic production are primarily composed of organic materials and occasionally small amounts of soluble nitrate or ammonium. All of these organic $\mathrm{N}$ sources, including SOM, will go through a mineralization process in which soil microbes metabolize organic carbon (C) and convert organic $\mathrm{N}$ compounds into ammonium and a subsequent process that quickly oxidizes the ammonium to nitrate (nitrification). These processes are part of a dynamic cycle of $\mathrm{N}$ in soil that to a large extent determines the rate and availability of mineral $\mathrm{N}$ to the growing crop (Fig. 1).

Nitrogen mineralization is always coupled with immobilization in the soil environment, and a complex set of factors determines whether $\mathrm{N}$ is released for plant uptake or remains immobilized by soil microbes (Jarvis et al., 1996). Mineralization rates are affected by soil temperature and moisture conditions as well as by the accessibility and nature of the organic matter (Flavel and Murphy, 2006; Hadas et al., 2004; Hartz and Johnstone, 2006; Leirós, 1999). As ammonium or nitrate are released, both are assimilated rapidly by soil microbes to oxidize new carbon substrates (i.e., $\mathrm{N}$ is immobilized). However, this $\mathrm{N}$ will subsequently be available for mineralization as the soil microbe population turns over (Jarvis et al., 1996). Estimating and predicting the amount and timing of $\mathrm{N}$ mineralization is complicated because of the numerous factors affecting the process. The most important of those factors are: 1) soil temperature (below

\begin{tabular}{llll}
\hline $\begin{array}{l}\text { Units } \\
\begin{array}{l}\text { To convert U.S. to SI, } \\
\text { multiply by }\end{array}\end{array}$ & U.S. unit & SI unit & $\begin{array}{l}\text { To convert SI to U.S., } \\
\text { multiply by }\end{array}$ \\
\hline 2.5400 & inch $(\mathrm{es})$ & $\mathrm{cm}$ & 0.3937 \\
1.1209 & $\mathrm{lb} / \mathrm{acre}$ & $\mathrm{kg} \cdot \mathrm{ha}^{-1}$ & 0.8922 \\
2.2417 & ton/acre & $\mathrm{mg}^{\circ} \mathrm{ha}^{-1}$ & 0.4461 \\
$\left({ }^{\circ} \mathrm{F}-32\right) \div 1.8$ & ${ }^{\circ} \mathrm{F}$ & ${ }^{\circ} \mathrm{C}$ & $\left(1.8 \times{ }^{\circ} \mathrm{C}\right)+32$
\end{tabular}

Horthannotas $\cdot$ October-December $200717(4)$ 


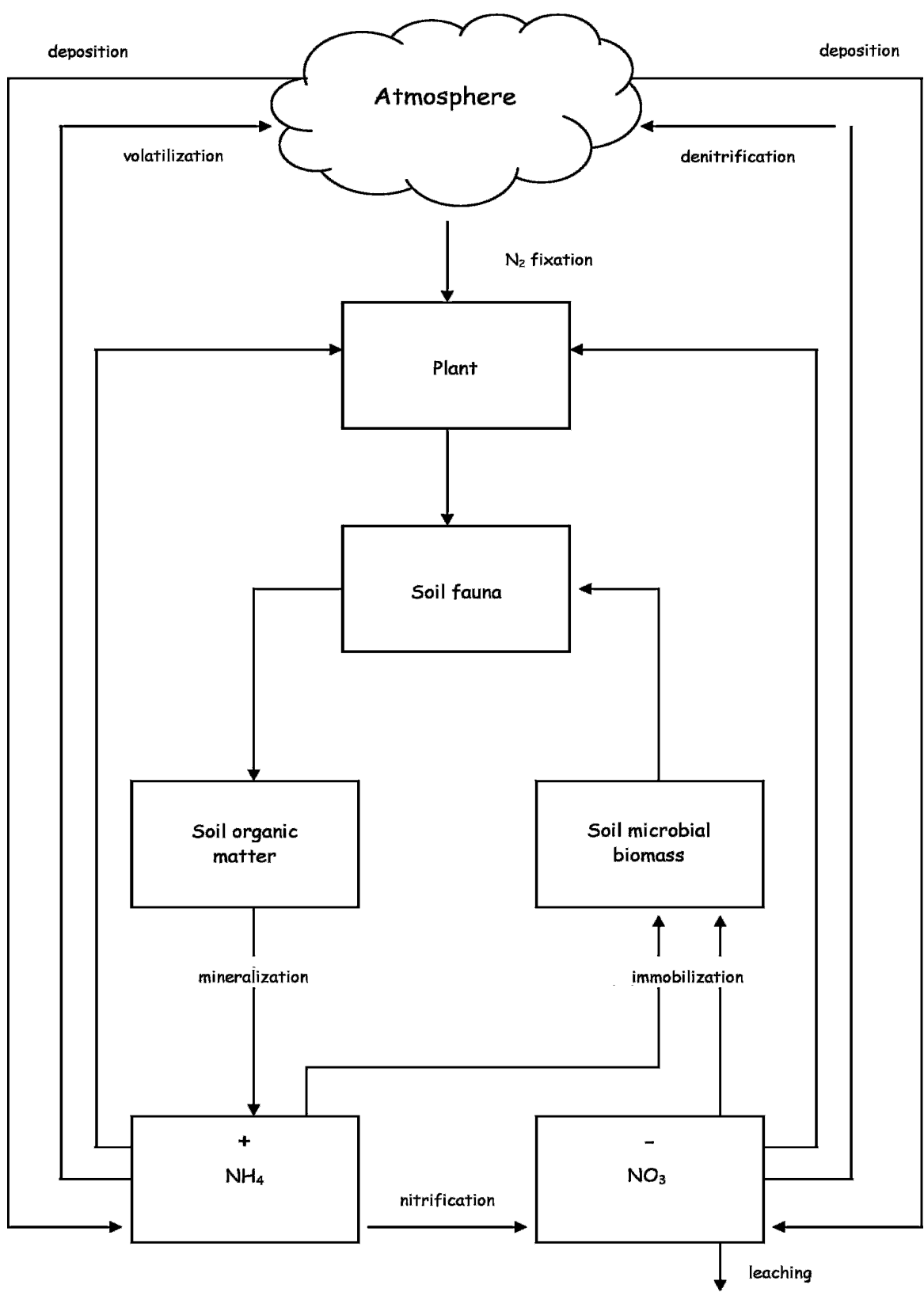

Fig. 1. The nitrogen cycle illustrating key nitrogen transformations including: fixation of atmospheric nitrogen $\left(\mathrm{N}_{2}\right)$, mineralization of soil organic matter to ammonium $\left(\mathrm{NH}_{4}{ }^{+}\right)$, nitrification to nitrate $\left(\mathrm{NO}_{3}{ }^{-}\right)$, and immobilization of nitrogen (from Jarvis et al., 1996).

$10{ }^{\circ} \mathrm{C}$, mineralization is limited, but above that temperature, mineralization increases as soil temperature increases); 2) soil moisture (mineralization proceeds rapidly in moist soils but is inhibited by either excessively wet or dry conditions, although moisture effects are difficult to predict) (Agehara and Warnacke, 2005); and 3 ) tillage practices (soil tillage stimulates a temporary increase in microbial activity and mineralization, which declines over the course of days help apply knowledge of SOM cycling to organic soil fertility (Horwath et al., 2002; Stevenson, 1994). Decomposition of the organic matter from plants and animals by soil microbes and fauna leads to the formation of humic substances that account for more than $70 \%$ of SOM. This humus is the more mature fraction and is more resistant to decomposition and may last for hundreds of years. The passive component consists in large part of the humus or heavy fraction and affects overall physical and chemical properties in soil. High $\mathrm{C}: \mathrm{N}$ ratio crop residues such as straw or corn stalks decompose slowly on incorporation and are more often converted to humus. Raising humus levels in soils is valuable as a long-term source of nutrients and also because it improves many soil physical and chemical properties associated with improvements in soil structure.

The remaining fraction of organic matter is composed of a range of material, including recent plant litter and highly decomposed unrecognizable plant and other organic residues. This organic matter is referred to as the particulate organic matter or active component or light fraction. The active component is labile and is readily mineralized and contributes more directly to nutrient dynamics. It is composed primarily of lush plant residues, root exudates, and microbial biomass. For instance, low C:N ratio residues from young legumes or vegetable crop residue produce less humus, decompose quickly, and contribute more to the light fraction of SOM. The active component is more responsive to management and markedly affects short-term nutrient cycling and plant nutrient availability (Stevenson, 1994).

It is difficult to increase overall SOM more than $1 \%$ in intensive vegetable-growing systems with residues that are low carbon/nitrogen, but even modest gains in SOM in these soils markedly improves cation exchange capability, nutrient cycling, and nutrient availability. Annual rates of SOM decomposition in most soils do not exceed $2 \%$ to $5 \%$ (Paul and Clark, 1996), but SOM nevertheless is an important source of nutrients in organic production systems. In many vegetable production systems, the quantity and timing of $\mathrm{N}$ availability is especially critical as a result of the 
relative short growing cycle (as compared with grain crops) and the marked effects of $\mathrm{N}$ sufficiency on vegetable yield and quality.

In summary, SOM drives the cycling of nutrients in soil, increases the ability to retain nutrients in soils, provides a habitat for a diversity of soil organisms, and creates a favorable environment for plant growth. The key to controlling nutrient availability for organic vegetable production is management to enhance the decomposition of the active fraction of SOM along with inputs to influence its size and composition (Horwath, 2004; Horwath et al., 2002).

\section{Cover crops, green manure, and forage crops}

Cover crops are cereals, annual or perennial grasses, or legumes used to cover the soil-often for a period of several months-between vegetable crops. They prevent erosion and when plowed under contribute organic matter and nutrients for subsequent crops. Forage crops are similar species used for feeding animals and usually occupy the land for 1 year or more. Ultimately, they are credited for their nutrient value when they are incorporated. Green manure crops (GM) refer specifically to cover crops grown for their nutrient value. The GM crops, incorporated for their $\mathrm{N}$ content and organic matter value, can play an important role in managing $\mathrm{N}$ for organic vegetable production. As a complement to $\mathrm{N}$ from SOM, a vigorous GM crop may be the most economical organic source of additional early-season $\mathrm{N}$ for the succeeding crop (although opportunity costs of GM crops can be considerable on high rent land) (Tourte et al., 2003). A GM crop is valuable not only because its biomass adds to SOM, but because the crop absorbs excess $\mathrm{N}$ after a cash crop and reduces nitrate leaching, nutrient runoff, and soil erosion. Cereals and other grasses and mustards (Brassica spp.) are particularly good at absorbing residual soil nitrate. Legumes, in addition to absorbing residual $\mathrm{N}$, also add additional $\mathrm{N}$ through fixation of atmospheric $\mathrm{N}$.

In vegetable production areas with mild climates such as California, GM crops are widely used in organic farming systems because they grow during the fall, winter, and early spring and can develop substantial biomass. Mineralization continues in the fall and winter in these areas because soil temperatures remain above $10{ }^{\circ} \mathrm{C}$, so the potential exists for leaching losses of nitrate and contamination of groundwater and neighboring surface water bodies. Under these conditions, cereal GM crops have been shown to reduce nitrate leaching by $65 \%$ to $70 \%$ (Wyland et al., 1996). In colder temperate vegetable production areas with little potential for growth over the winter months, GM crops grow more slowly and mineralization slows or halts as a result of cold soils. A GM crop still can absorb some excess nutrients in these colder areas, but they develop less crop biomass and $\mathrm{N}$ for incorporation before late spring planting.

A vigorous GM growing for 4 to 6 months before incorporation typically adds between 100 and 200 $\mathrm{lb} /$ acre $\mathrm{N}$ to the soil for the succeeding crop. A GM crop in colder climates with less accumulated biomass when incorporated will contribute considerably less N. A study with organic bell pepper (Capsicum annuum) production in California evaluated the effects of a prior GM [composed of vetch (Vicia sativa), fava beans (Vicia faba), and barley (Hordeum vulgare)] before application of varying rates of $\mathrm{N}$ as granular feather meal (Gaskell, 2004). This study found that pepper yields increased with increasing rates of $\mathrm{N}$ as feather meal and that yields at $100 \mathrm{lb} /$ acre $\mathrm{N}$ as feather meal with a prior incorporated GM were the same as pepper yields with $200 \mathrm{lb} /$ acre $\mathrm{N}$ without a GM. In effect, the GM supplied the equivalent of $100 \mathrm{lb} /$ acre $\mathrm{N}$.

Within the first year after GM incorporation, only a small portion of the GM-N will typically be used by the next crop. The $\mathrm{N}$ recovery rates for a crop after legumes range from $10 \%$ to $50 \%$ of the GM-N (Hadas et al., 2004). This is attributable in part to immobilization of $\mathrm{N}$ by soil microorganisms (Jackson, 2000) and also to the fact that the $\mathrm{N}$ is liberated from the residues very quickly, before the greatest need of the crop (Crews and Peoples, 2005; Myers et al., 1994). In a study with nitrogen-15, GM-N recovery was low in the subsequent crop but was high (73\%) after five subsequent crops (Crews and
Peoples, 2005). Similar results were reported for a mixed tomato (Solanum lycopersicum) and corn cropping system in California (Poudel et al., 2001 ). It appears that although shortterm recovery may be low, GM- N remains in the soil humus system for a period of years and slowly becomes available to subsequent crops.

Leguminous GM or vegetable crop residues decompose readily leading to rapid $\mathrm{N}$ mineralization for crop uptake. The majority of nitrate-N mineralized from a low $\mathrm{C}: \mathrm{N}$ ratio (less than 20) GM occurs over a 3- to 6 -week period after incorporation and then the soil nitrate- $\mathrm{N}$ level returns to preincorporation levels by week 6 to 8 in moist, pH-neutral soils (Fig. 2). Therefore, a GM can be a valuable source of short-term N, but longerseason vegetable crops after a GM will require additional sources of $\mathrm{N}$ later in the season (Gaskell et al., 2006).

When $\mathrm{N}$ from a GM is mineralized, it can be taken up and used by the crop or lost through leaching during irrigation or rainy periods. For instance, a recent study in Monterey County, CA, showed that a GM residue that received $30 \mathrm{~cm}$ of rain lost the equivalent of $50 \mathrm{lb} /$ acre $\mathrm{N}$ (J. Muramoto and R. F. Smith, unpublished data). For this reason, planting of vegetable crops should occur relatively soon after GM incorporation. This period can vary with the type of GM mix because a GM with a greater percentage of a cereal or grass in the mix may require more time to decompose to be able to work the soil into an adequate seedbed.

The rate of $\mathrm{N}$ release from the GM is affected by the composition of the GM and the $\mathrm{C}: \mathrm{N}$ ratio of the residue (Horwath, 2004; Jarvis et al., 1996). The concept of varying $\mathrm{C}: \mathrm{N}$ ratio of the GM species mix to improve the timing of $\mathrm{N}$ availability from GM (Kuo and Sainju, 1998) can potentially be applied to a variety of organic amendments and cropping systems (Horwath, 2004). Mixtures of legumes and grasses are a common strategy for GM production because the grass grows more vigorously at the outset and can compete more effectively with weeds. The grass also uses residual soil $\mathrm{N}$, reducing high soil $\mathrm{N}$ concentrations that might otherwise inhibit $\mathrm{N}$ fixation by the legume. Mixtures also ensure that the GM is productive under a range of 


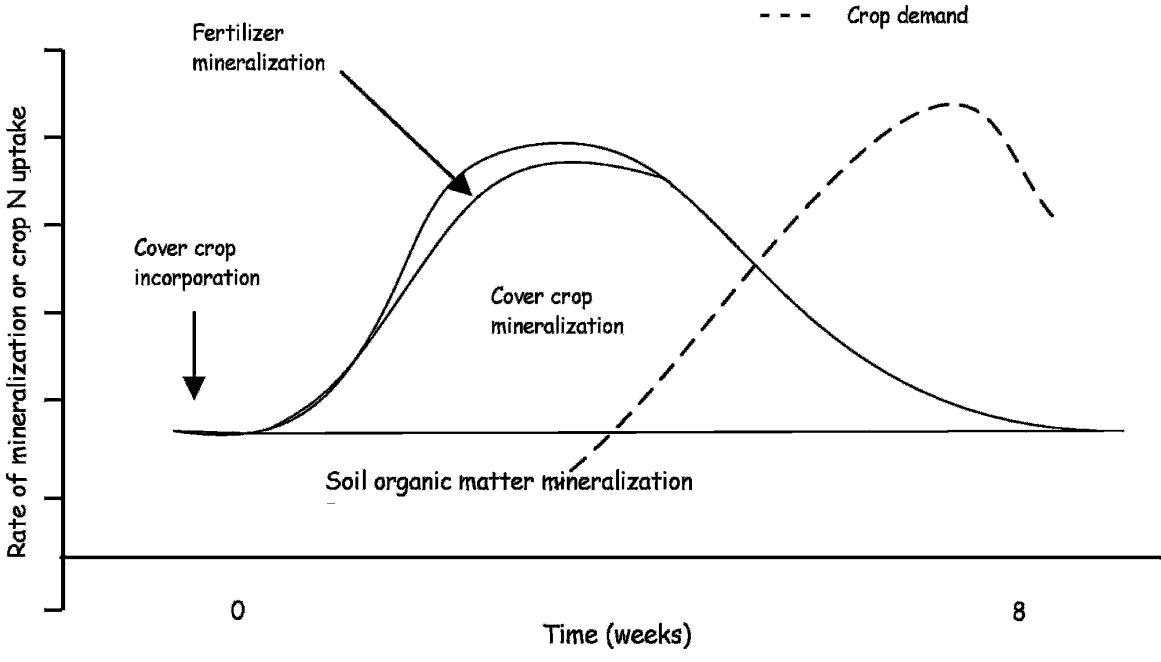

Fig. 2. Timing of nitrogen $(\mathrm{N})$ mineralization from soil organic matter, cover crop residue, and organic fertilizer in relation to crop $\mathrm{N}$ uptake (from Gaskell et al., 2006).

weather conditions as a result of the different environmental tolerances of the various plant species.

Green manure crops have an important direct role as $\mathrm{N}$ nutrient sources in addition to their overall value in enhancing SOM and absorbing excess available $\mathrm{N}$ and other nutrients. The challenge for effective and efficient use of GM for organic vegetable production will be selecting the appropriate GM mix and associated cultural practices tailored to the specific needs of the succeeding vegetable crop.

\section{Animal manure}

Manure is less used in vegetable production systems than in more traditional grain production systems or rotations involving animal agriculture. The U.S. Department of Agriculture (USDA) National Organic Program (NOP) Section 205.203 Soil fertility and crop nutrient management practice standard (USDA, 2007) restricts manure use to composted manure "unless it is:

(i) Applied to land used for a crop not intended for human consumption;

(ii) Incorporated into the soil not less than $120 \mathrm{~d}$ before the harvest of a product whose edible portion has direct contact with the soil surface or soil particles; or

(iii) Incorporated into the soil not less than $90 \mathrm{~d}$ before the harvest of a product whose edible portion does not have direct contact with the soil surface or soil particles" (USDA, 2007).

Each of these restrictions represents serious use limitations for uncomposted manure by vegetable growers. In addition to these practical limitations, fresh produce marketers have voiced reservations about having manure in any way associated with their production operations, thus avoiding consumer concern or hesitation at the point of purchase. Thus, most commercial vegetable operations will only use composted manure-a very different product with different biological properties-as an $\mathrm{N}$ source for vegetables. Manures may in some instances be used in a long rotation out of vegetables or to build SOM. but their value as an available $\mathrm{N}$ source for the next vegetable crop would be limited. For all practical purposes, manure is not a useful near-term source of $\mathrm{N}$ for most organic vegetable crops.

\section{Compost}

In the composting process, green wastes, crop residues, animal manures, and other organic waste materials are aerobically transformed by microbial decomposition. The mineral and organic $\mathrm{N}$ forms are stabilized as organic matter that more closely resembles SOM than the original components. Much of the previous discussion of mineralization in the SOM section also pertains to compost. However, compost is treated as an amendment from on-farm or offfarm sources. The rate, timing, and technique of application can be more closely controlled by the grower, but compost quality can vary markedly from different sources and from the same source at different times of the year (Hartz et al., 2000).

Compost application can increase yields when used as a primary source of $\mathrm{N}$ at sufficiently high rates. Roe and Cornforth (2000) reported an $\mathrm{N}$ rate response to applied compost for muskmelon (Cucumis melo) and broccoli (Brassica oleracea var. italica) crops, but not at economically feasible application rates. Additionally, only relatively small amounts of the total $\mathrm{N}$ applied is available to the succeeding crop (Gaskell et al., 2006; Hartz et al., 2000). The N availability from compost to the succeeding crop is quite variable ranging from negative (Douglas and Magdoff, 1991) to low N recovery rates of $4 \%$ to $15 \%$ (Castellanos and Pratt, 1981; Hartz et al., 2000; Kirchmann, 1989; Tyson and Cabrera, 1993) to a high rate of $57 \%$ (Buchanan and Gliesmann, 1991). Compost is typically $1 \%$ to $2 \% \mathrm{~N}$ on a dry weight basis. When 100 to $200 \mathrm{lb} /$ acre of $\mathrm{N}$ may be needed for the fertilized crop, using compost as the primary source of $\mathrm{N}$ may routinely require rates of application of 25 to 30 tons/acre or more (Berry et al., 2002). There are additional benefits from compost application beyond its value for $\mathrm{N}$ (e.g., soil tilth improvement), and it is also a balanced source of other plant nutrients. However, the uncertainty of nutrient availability can lead to over- or underfertilization of the crop and subsequent potential hazard of $\mathrm{N}$ or phosphorus $(\mathrm{P})$ contamination of ground or surface waters. Clearly, there are important limitations for organic vegetable growers who base their $\mathrm{N}$ fertility program solely on compost (Gaskell et al., 2006; Mikkelsen, 2000).

Costs of compost can vary widely depending largely on hauling distances from the point of manufacture and the availability and cost of feed stocks. Composts are typically $25 \%$ to $35 \%$ moisture and their composition is reported on a dry weight basis, which immediately increases costs per unit $\mathrm{N}$ proportionately. There are additional hidden costs related to storing, mixing, and applying 
compost and the potential losses from volatilization and nitrate leaching and runoff from stored compost. The uncertainty associated with such factors as the nature of the compost material, particle size distribution, uniformity of application, and so on, combined with additional costs for storage facilities and equipment for loading and applying compost increase the actual costs per unit $\mathrm{N}$ from composts.

More commonly, low rates ( 3 to 4 tons of compost per acre) are used for preplant incorporation in those instances when a prior cover crop is not available or the compost amendment is desirable for other nutrients or to enhance SOM and improve soil physical properties. Field studies with compost mineralization confirm that a high-quality, low C:N ratio compost can release low levels of nitrate- $\mathrm{N}$ over an initial 4- to 6-week period after incorporation (Gaskell, 2004). This observation coupled with typical application rates mean that compost can serve as an $\mathrm{N}$ source for a seeded or transplanted vegetable crop for the first 4 to 5 weeks of the season or possibly as the sole source of $\mathrm{N}$ for a short-cycle leafy "baby" vegetable. Repeated compost addition can also contribute to SOM and the longterm soil $\mathrm{N}$ reservoir (Poudel et al., 2001).

\section{Commercial organic fertilizers}

Many types of dry and liquid commercial organic fertilizers are available for use in certified organic vegetable production. Most of these products are byproducts of fish, livestock, and food and other processing industries. Various single-source and blended organic products are available from different fertilizer suppliers and distributors. Some typical examples of organic fertilizer sources and their composition are listed in Table 1.

Organic fertilizers are important for supplementing $\mathrm{N}$ mineralized from SOM, GM, and compost. They are particularly important in supplying late-season $\mathrm{N}$ to optimize crop yield and quality. Commercial organic $\mathrm{N}$ fertilizers are more concentrated $\mathrm{N}$ sources than compost with improved handling, $\mathrm{N}$ placement, and $\mathrm{N}$ availability. When added to soil, these materials act much as incorporated GM residues in the mineralization/ immobilization cycle (Fig. 1) with the availability of mineral $\mathrm{N}$ related to the interaction of environmental factors described previously.

Hartz and Johnstone (2006) and Gaskell et al. (2006) reported the mineralization rates of fish powder, blood meal, feather meal, and seabird guano at varying incubation temperatures from 10 to $25^{\circ} \mathrm{C}$ (Table 2). The results are similar to $\mathrm{N}$ mineralization previously reported for feather meal and seabird guano (Hadas and Kautsky, 1994; Hadas and Rosenberg, 1992; Smith, 2001). Mineralization was more rapid at warmer temperatures for the organic fertilizers in the study summarized in Table 2; and the patterns of $\mathrm{N}$ mineralization were consistent with results reported for SOM, GM, or compost incorporation with tillage.
Although the $\mathrm{N}$ release rates are similar between the high $\mathrm{N}$ organic fertilizers and compost, the magnitude of $\mathrm{N}$ release from the fertilizers is greater because the percent of $\mathrm{N}$ release is greater. The different types of organic fertilizers are potentially useful as $\mathrm{N}$ sources during the season, but their cost per unit $\mathrm{N}$-already higher than conventional mineral $\mathrm{N}$ sources such as urea or ammonium nitrate-is considerably higher when the smaller fraction of $\mathrm{N}$ mineralized over the life of the crop is calculated. A proportion of the $\mathrm{N}$ from these materials will be available to the current crop, immobilized and mineralized by soil microbes, or lost to leaching.

There are relatively few research reports evaluating these commercial products or their source materials in

Table 1. Common organic nitrogen (N) fertilizer materials and their nutrient analysis. ${ }^{\mathrm{z}}$

\begin{tabular}{lccc}
\hline Material & $\begin{array}{c}\text { Nitrogen } \\
(\% \mathbf{~ N})\end{array}$ & $\begin{array}{c}\text { Phosphorus } \\
(\% \mathbf{~ P )}\end{array}$ & $\begin{array}{c}\text { Potassium } \\
(\mathbf{\%} \mathbf{~ K})\end{array}$ \\
\hline Fish meal or powder & $10-11$ & 1.3 & $<1$ \\
Pelleted chicken manure & $2-4$ & $<1$ & $<1$ \\
Processed liquid fish residues & 4 & $<1$ & $<1$ \\
Feather meal & 12 & 0 & 0 \\
Seabird and bat guano & $9-12$ & $<1-1.75$ & $<1$ \\
Alfalfa meal (Medicago sativa) & 4 & $<1$ & $<1$ \\
Soybean meal (Glycine max) & 7 & $<1$ & $<1$ \\
Bone meal & 2 & $<1$ & 0 \\
Kelp (order Laminariales) & $<1$ & 0 & 1.7 \\
Chilean nitrate & 16 & 0 & 0 \\
Blood meal & 12 & 0 & 0 \\
Meat and bone meal & 8 & 2.2 & $<1$ \\
\hline
\end{tabular}

${ }^{2}$ Gaskell et al., 2006.

Table. 2. Mineralization rates of several typical organic fertilizer materials at two temperature regimes. ${ }^{\mathrm{z}}$

\begin{tabular}{lcccc}
\hline & & \multicolumn{3}{c}{$\begin{array}{c}\text { Proportion of initial organic } \\
\text { nitrogen }\end{array}$} \\
\cline { 2 - 5 } Product & Temp $\left({ }^{\circ} \mathbf{C}\right)^{\mathbf{y}}$ & 1 wk & 4 wk & $\mathbf{8}$ wk \\
\hline Pelleted poultry manure & 15 & 4 & 16 & 21 \\
Sea bird guano & 25 & 10 & 23 & 36 \\
Pelleted seabird guano & 15 & 49 & 57 & 60 \\
Fish powder & 25 & 45 & 48 & 54 \\
& 15 & 42 & 61 & 64 \\
Feather meal & 25 & 46 & 60 & 67 \\
\multirow{2}{*}{ Blood meal } & 15 & 51 & 55 & 61 \\
& 25 & 48 & 60 & 64 \\
& 15 & 42 & 56 & 59 \\
& 25 & 50 & 64 & 63 \\
& 15 & 41 & 60 & 64 \\
\hline
\end{tabular}

${ }^{7}$ Gaskell et al., 2006; Hartz and Johnstone, 2006.

${ }^{\mathrm{y}}\left(1.8 \times{ }^{\circ} \mathrm{C}\right)+32={ }^{\circ} \mathrm{F}$. 
controlled field trials (Aung and Flick, 1980; Gaskell, 2001, 2004; Gaskell et al., 2000; Smith, 2001). Studies have shown the usefulness of commercial fertilizer products for growing organic vegetable transplants (Russo, 2005). The timing of fertilizer use and $\mathrm{N}$ availability are critical to their effectiveness. Effectiveness can most efficiently be inferred from greenhouse or laboratory incubation evaluations for the individual source materials (Hartz and Johnstone, 2006), but Jarvis et al. (1996) expressed reservations about the application of these types of incubation studies to mineralization in situ.

One field study showed that applications of guano were the most effective of several materials evaluated in supplying supplemental $\mathrm{N}$ for optimal yield (Smith, 2001). Hadas and Rosenberg (1992) and Hartz and Johnstone (2006) reported that seabird guano was one of the most efficient organic sources of mineralized $\mathrm{N}$ based on incubation studies. This corresponded well with field studies with multiple materials on organic fields reported by Gaskell (2004). Gaskell (2004) also reported relatively high $\mathrm{N}$ availability from feather meal and some liquid fish residue materials.

In addition, given the lag in the release of mineral nitrogen after the application of these fertilizer materials, the timing of application was an important consideration. For instance, applications of organic $\mathrm{N}$ fertilizers early in the growth cycle of transplanted broccoli gave improved yields compared with later sidedress applications, presumably because the early applications synchronized more effectively with crop $\mathrm{N}$ demand (Smith, 2001). These results indicate that growers need to carefully consider the release pattern of the fertilizer materials and how the pattern matches the demand of the crop. Given the diversity of materials and their inherent variability, it is difficult to standardize the products for evaluation.

Mined "Chilean nitrate," a source of sodium nitrate that is soluble and more readily plant-available compared with the other organic materials, represents a special case for organic growers. It has historically been an important organic $\mathrm{N}$ source for some organic growers because it is relatively economical, soluble, and comparatively easy to use. Objections to its use are related to: 1) the mining and use of this product may create environmental degradation related to repeated sodium application to soils, 2) the contamination from small amounts of perchlorate that are a natural component of the Chilean nitrate, and 3) the view among organic certifying agencies that reliance on a soluble, mineral $\mathrm{N}$ fertilizer is incompatible with organic principles. The USDA NOP currently restricts use of Chilean nitrate to no more than $20 \%$ of total annual $\mathrm{N}$ use and mandates that organic producers develop a plan to phase out Chilean nitrate use over time.

Liquid organic fertilizers as a group (e.g., liquid fish, soybean meal, and so on) offer special opportunities and special challenges for efficient $\mathrm{N}$ use. Increasing adoption of drip and microirrigation in fruit and vegetable production offers promise for water conservation and for improving $\mathrm{N}$ use efficiency. With the relatively high costs of organic fertilizers coupled with their inefficient use, even small improvement is important. Liquid fertilizers, however, present additional potential problems for application through microirrigation systems. The liquid organic fertilizers as typically applied lack uniformity because they are subject to settling and microbial transformation may occur in anaerobic conditions. The nutrient composition reported for the liquid organic fertilizers includes organic material in suspension that may be filtered out of microirrigation systems to avoid plugging. Such material does not reach the crop, increasing fertilization uncertainty and complicating $\mathrm{N}$ requirement calculations, and markedly increasing unit $\mathrm{N}$ costs of the materials. Nevertheless, some of the liquid fish-derived and soybeanbased materials fertilizer materials are widely used in organic vegetable production, and many growers report satisfaction overall with these products.

Mineralization is a highly variable process and despite decades of study, we currently have insufficient predictive capability regarding the timing and rate of release of $\mathrm{N}$ from mineralization (Jarvis et al., 1996). Additionally, organic fertilizer materials by nature are subject to quality variability; this is the result of natural processes, heating and cooling, wetting and drying, and physical redistribution and settling, which affect product uniformity. This variability is further complicated by difficulties associated with uniform application of the materials to optimize mineralization and crop $\mathrm{N}$ uptake. All of these factors make precise management with organic fertilizers very challenging, but despite the challenges, vegetable growers are reliant on them to achieve acceptable yield and quality.

For acceptability of different potential organic fertilizer materials under the USDA NOP, U.S. organic growers are encouraged to consult their certifying agency. The Organic Materials Review Institute (OMRI) is an independent entity that provides an evaluation of products intended for use in certified organic production, handling, or processing. The OMRI Products List is intended to verify whether materials are acceptable under the USDA NOP. The National Organic Standards list may be accessed from the USDA NOP web site (USDA, 2007).

\section{Nitrogen uptake versus nitrogen availability}

Horticultural crops are often more dependent than agronomic crops on nutrients imported from off the farm (Watson et al., 2002). In intensive vegetable cropping systems, the economics of land use often dictate continuous cash cropping of alternating vegetable crops on highvalue land with year-round cropping potential (Hartz, 2002). Animals are not traditionally a part of this system and animal residues may not be locally available. Land is intensively cropped and in mild production areas, there is often an emphasis on production for early- or late-season markets because of their associated price premiums. As a result, there may not always be an off-season period in which a GM crop could be used to add $\mathrm{N}$ or $\mathrm{C}$ to the system (Tourte et al., 2003). Seasonal $\mathrm{N}$ uptake patterns have been summarized for a number of crops, including vegetable crops (Sullivan et al., 1999). The overall $\mathrm{N}$ demand pattern is similar for all crops, but the slope and duration of the uptake curve is species-specific and is also 
affected by environmental conditions (Fig. 3).

\section{Asynchrony of nitrogen availability}

The timing of $\mathrm{N}$ mineralization from a GM may be a serious limitation for the use of a GM as the primary source of $\mathrm{N}$ for an organic vegetable crop. Incorporation of a GM often leads to a rapid release of nitrate- $\mathrm{N}$ followed by subsequent decline (Campbell et al., 1994; Doran and Smith, 1991; Sarrantonio and Scott, 1988; Scow, 1996), and this asynchrony of $\mathrm{N}$ availability for plant uptake seriously limits production (Doran et al., 1996; Robertson, 1997; Wagger, 1989). The $\mathrm{N}$ released from an incorporated vetch GM was not adequate for a subsequent tomato or corn crop even when supplemented with preplant poultry manure (Cavero et al., 1997; Scow, 1996; Temple et al., 1994). Other studies have shown contradictory results, however, at least for a short-season sweet corn crop. Griffin et al. (2000) and Cline and Silvernail (2002) report that leguminous GM crops in a temperate environment can fully satisfy $\mathrm{N}$ requirements of the subsequent sweet corn crop. Other studies report that a prior legume GM crop provided $\mathrm{N}$ equivalent to 38 to $120 \mathrm{~kg} \cdot \mathrm{ha}^{-1} \mathrm{~N}$ to a subsequent tomato crop, but highest tomato yields were observed with 150 $\mathrm{kg} \cdot \mathrm{ha}^{-1} \mathrm{~N}$ as fertilizer $\mathrm{N}$ (Thönnissen et al., 2000). Clearly, managing $\mathrm{N}$ from a GM crop is considerably more complex than managing $\mathrm{N}$ from $\mathrm{N}$ fertilizers (Shennan, 1992).

In Figure 3, Phase I of the curve occurs during the early season when growth is relatively slow and the plant demands for $\mathrm{N}$ are low. Phase II is the period when growth rate and $\mathrm{N}$ uptake are at their highest and plant demand for $\mathrm{N}$ is high. Phase III is the final growth period when little additional $\mathrm{N}$ is taken up, but rather $\mathrm{N}$ is redistributed in the plant while the plant continues to accumulate biomass and C. Phase III primarily pertains to grain crops, however, and with fresh vegetable crops, there is little or no Phase III. Most fresh vegetables would be harvested at the end of Phase II.

The time in each of the three phases and the daily $\mathrm{N}$ uptake has been summarized for broccoli
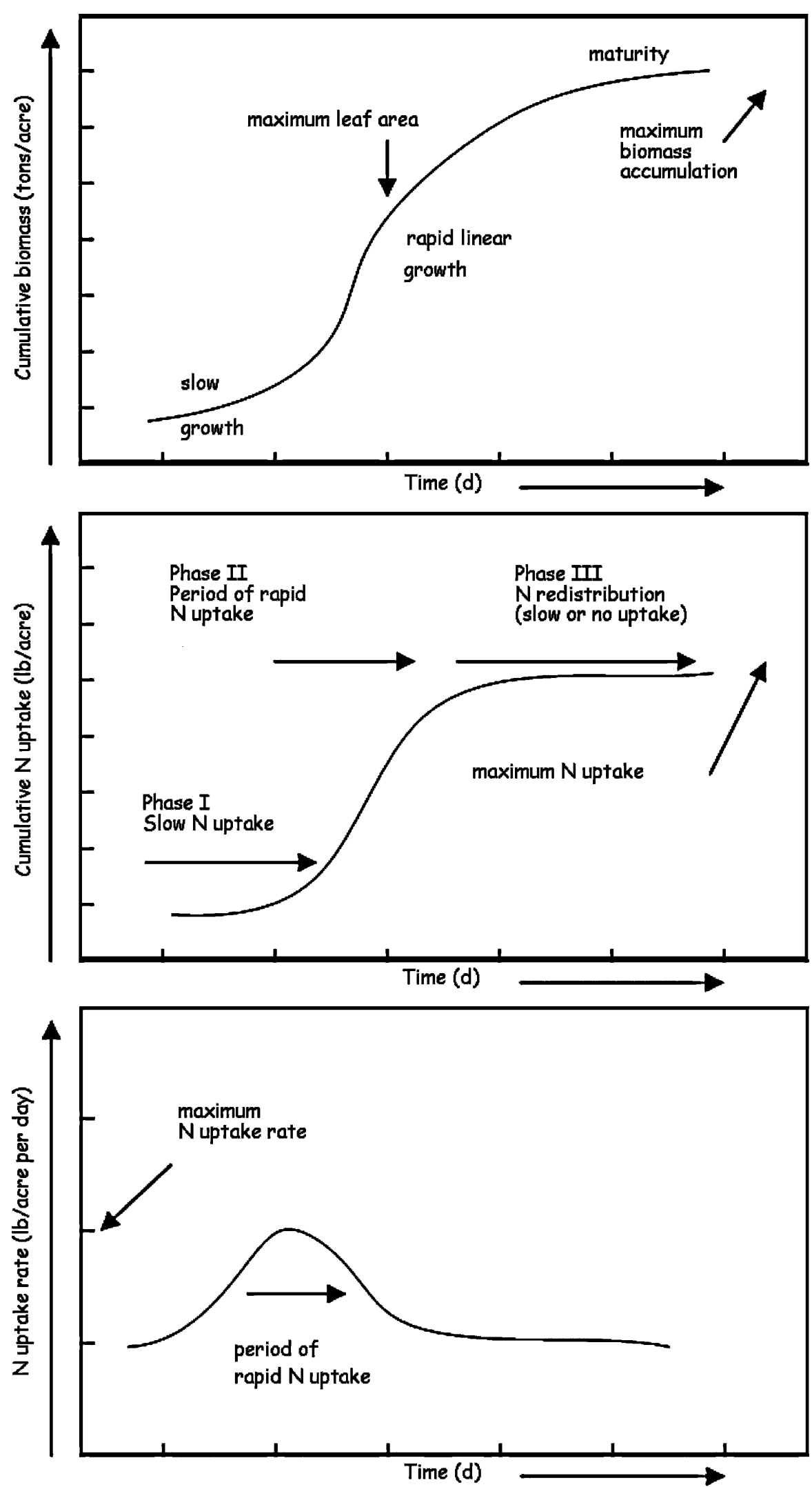

Fig. 3. Illustration of typical phases of crop nitrogen $(\mathrm{N})$ uptake rate $(\mathrm{lb} / \mathrm{acre}$ per day) and cumulative $\mathrm{N}$ uptake in $\mathrm{lb} / \mathrm{acre}\left(1 \mathrm{lb} / \mathrm{acre}=1.1209 \mathrm{~kg} \cdot \mathrm{ha}^{-1}\right)$ compared with biomass accumulation in ton/acre ( 1 ton/acre $=2.2417 \mathrm{mg} \cdot \mathrm{ha}^{-1}$ ) (Sullivan et al., 1999). 
(Sullivan et al., 1999). Broccoli typically is in Phase II-the period of most rapid plant $\mathrm{N}$ demand-for the period from 50 to $90 \mathrm{~d}$ after planting and during this period, maximum uptake reaches 4 to $7 \mathrm{lb} /$ acre $\mathrm{N}$ per day (Fig. 4).

This period when peak $\mathrm{N}$ demand occurs can be satisfied from an organic $\mathrm{N}$ source, but mineralization of $\mathrm{N}$ from SOM is not rapid enough to satisfy this demand (Hartz et al., 2000; Krusekopf et al., 2002). By Phase II, N release from preplantincorporated GM or compost (Hartz et al., 2000) has peaked and the inorganic $\mathrm{N}$ concentration returned to background soil N levels (Gaskell, 2004, (Gaskell et al.,2006). The low availability of mineral $\mathrm{N}$ from organic sources and the dependence on $\mathrm{N}$ mineralization to supply $\mathrm{N}$ means that during periods of rapid crop growth and high $\mathrm{N}$ demand, a vegetable crop may deplete the $\mathrm{N}$ pool in the soil solution resulting in loss of yield or quality.

Some asynchrony is unavoidable in annual cropping systems (Crews and Peoples, 2005; Myers et al., 1994) and synchrony is harder to achieve with organic $\mathrm{N}$ sources than the more soluble materials available to conventional growers. Growers attempt to minimize $\mathrm{N}$ asynchrony with management practices to promote efficient $\mathrm{N}$ use. Such practices as presidedress nitrate testing, judicious use of highly available mineral $\mathrm{N}$ sources, and controlled-release fertilizers among others are used in conventional vegetable production, but these are for the most part not available to organic growers. Preplant incorporation of low-analysis organic sources and dependency on mineralization of these sources and SOM are some of the more economical forms of $\mathrm{N}$ management available to organic vegetable producers, but these offer little help for avoiding asynchrony of $\mathrm{N}$ availability. This situation is challenging and as a result, growers frequently rely on supplemental $\mathrm{N}$ from commercial organic fertilizers to meet the peak crop demand.

Research showing that different GM crops mineralize at different rates depending on their $\mathrm{C}: \mathrm{N}$ ratio or lignin or polyphenol content is also promising (Jarvis et al., 1996; Kuo and Sainju, 1998). Ideally, further research will enable the development of optimal GM mixtures to provide an extended release of $\mathrm{N}$. This could allow preplant-incorporated GM crops to extend the period of $\mathrm{N}$ mineralization and satisfy more of the phase of rapid crop $\mathrm{N}$ demand.

The overall plant nutrition and environmental consequences of asynchrony in a semiarid environment are less than those in a higher rainfall environment because leaching below the root zone is less likely, assuming irrigation management does not cause excessive leaching. The general trend toward drip irrigation in vegetable production systems improves $\mathrm{N}$ use efficiency in conventional vegetable production, and drip
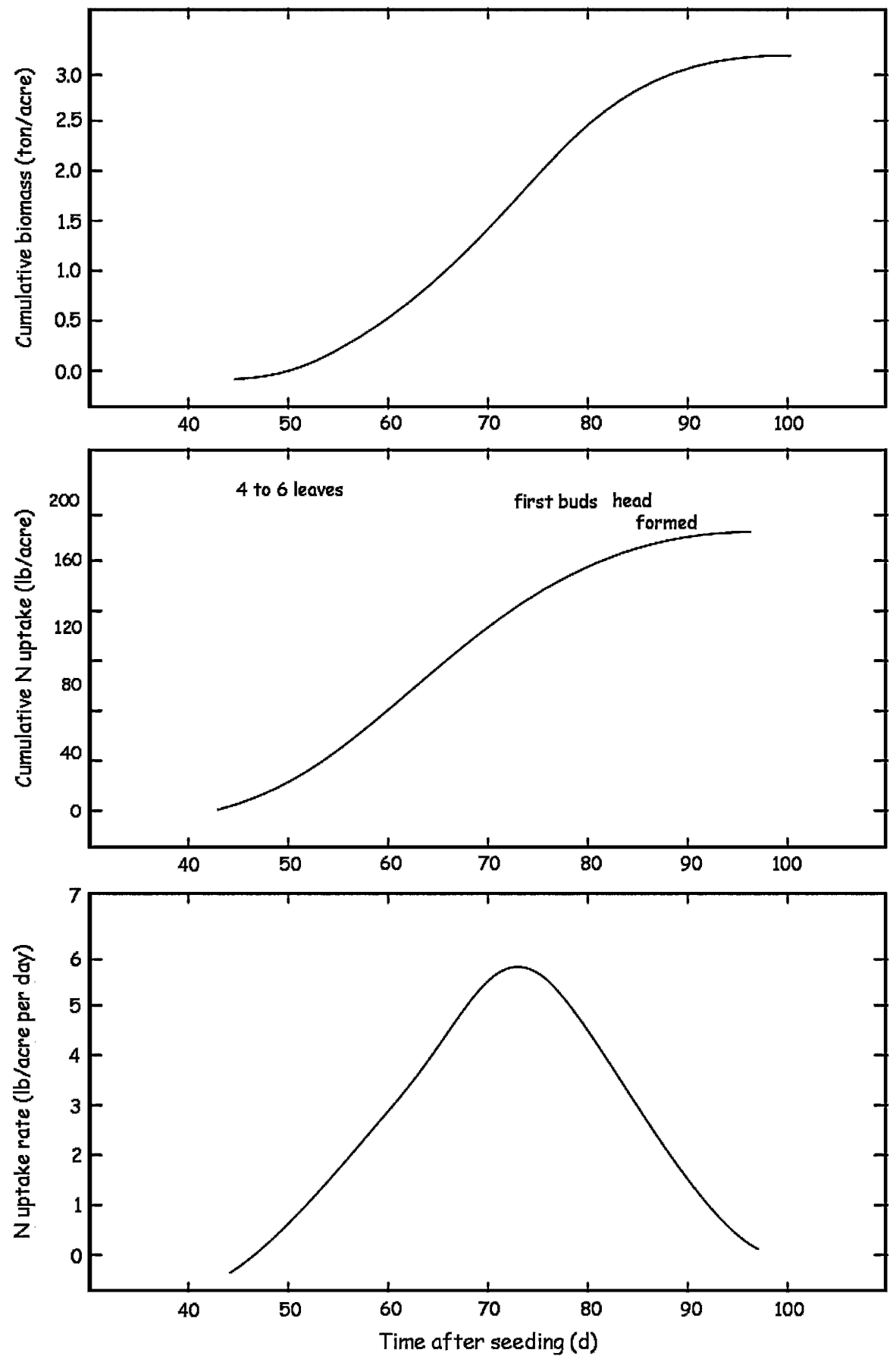

Fig. 4. Phases of broccoli crop nitrogen $(\mathrm{N})$ uptake rate (lb/acre per day) and cumulative $\mathrm{N}$ uptake in $\mathrm{lb} /$ acre $\left(1 \mathrm{lb} / \mathrm{acre}=1.1209 \mathrm{~kg} \cdot \mathrm{ha}^{-1}\right)$ compared with broccoli biomass accumulation in ton/acre $\left(1\right.$ ton $/$ acre $\left.=2.2417 \mathrm{mg} \cdot \mathrm{ha}^{-1}\right)$ (Sullivan et al., 1999). 
irrigation should help reduce asynchrony in organic production once liquid organic $\mathrm{N}$ fertilizers are better understood.

\section{Nitrogen losses}

There is considerable potential for $\mathrm{N}$ loss from organic $\mathrm{N}$ sources even from systems in which $\mathrm{N}$ is often limited. Nitrogen losses are higher overall in irrigated production environments such as intensive vegetable production than are seen in dry land production systems (Crews and Peoples, 2005), but improved productivity in irrigated systems helps improve $\mathrm{N}$ use efficiency. The lag period between peak residue or preplant organic $\mathrm{N}$ mineralization and crop mineral $\mathrm{N}$ uptake can mean that large amounts of nitrate may be available to leach or runoff with rainfall events. There can even be potential losses in situations in which a high $\mathrm{N}$ residue crop such as broccoli is incorporated during a high rainfall period, and the burst of nitrate that follows mineralization of the residue may be in excess of that needed by a newly seeded or transplanted crop. Problems are more severe in high rainfall areas or in irrigated areas during the rainy season (Stockdale et al., 2002). There can also be gaseous $\mathrm{N}$ losses resulting from volatilization of ammonia from surface-applied compost on a calcareous soil (He et al., 2003) as denitrification of nitrous oxides $\left(\mathrm{N}_{2} \mathrm{O}\right)$ and other $\mathrm{N}$ oxides $\left(\mathrm{NO}_{\mathrm{x}}\right)$, particularly in heavily fertilized and irrigated production systems (Smil, 1999). Volatilization may occur with other higher $\mathrm{N}$ analysis commercial organic fertilizers as well. Rapid incorporation of the material into the soil after application will help minimize volatilization. Production systems with higher $\mathrm{C}$ inputs have the potential for lower $\mathrm{N}$ losses (Poudel et al., 2001). Composts with a high $\mathrm{C}: \mathrm{N}$ ratio and high $\mathrm{C}$ amendments may be useful for managing $\mathrm{N}$ excesses by stimulating microbial immobilization; however, repeated compost application also presents a potential threat for $\mathrm{P}$ contamination if the soil P level already is elevated (Sharpley et al., 1994). Clearly, there is a need to improve $\mathrm{N}$ synchrony and $\mathrm{N}$ use efficiency in organic cropping systems to avoid crop deficiency or potential ground or surface water contamination from $\mathrm{N}, \mathrm{P}$, or other nutrients.
Finer-textured soils may support greater GM growth and have overall higher nutrient retention than sandier soils depending on the circumstances (i.e., water management, drainage, and so on). Loam soils generally have a higher potential to retain $\mathrm{N}$ mineralized from a GM or compost addition even when there is a large lag time between incorporation and crop uptake (Cherr et al., 2006). However, even in these soils, there is still considerable potential for $\mathrm{N}$ deficiency and/or $\mathrm{N}$ losses through leaching, volatilization, or denitrification in warm, humid environments.

Cover crops provide an important cultural practice for capturing residual nitrate in vegetable production fields and sequestering it in plant biomass during the rainy period, thereby reducing nitrate- $\mathrm{N}$ losses (Jackson, 2000; Jackson et al., 1993). In mild winter areas, $\mathrm{N}$ availability may be high in the fall and because soil temperatures remain high enough for mineralization to continue, the potential for $\mathrm{N}$ losses is high. Nonlegume cover crops such as grasses and Brassica species are often preferred because these cover crops can trap nitrate that would otherwise be lost by leaching or runoff. Nonlegumes may also be more tolerant of cooler temperatures than legumes. Studies in the California coastal production region have shown that 'Merced' rye (Secale cereale) can significantly reduce leaching of nitrate (Jackson et al., 1993). Winter-grown grass and mustard cover crops typically absorb 100 to $200 \mathrm{lb} /$ acre $\mathrm{N}$ in their aboveground biomass; these cover crops thereby capture or trap $\mathrm{N}$ that would otherwise be lost and contribute to environmental contamination. Legumes are also capable of scavenging residual $\mathrm{N}$ from soil, but grasses and mustards are more efficient at this process (Fageria et al., 2005). Mixes of grasses and legumes provide a blend of species that is efficient at both $\mathrm{N}$ trapping and $\mathrm{N}$ fixation.

Efficient $\mathrm{N}$ management presents special challenges for organic vegetable growers. Nitrogen is often the most limiting nutrient for vegetable production, and each organic $\mathrm{N}$ source has characteristics that require specific management to be most effective. Soil organic matter and GM crops are the most economical of organic $\mathrm{N}$ sources, and compost application is best used to build SOM reserves and to improve tilth. Commercial organic $\mathrm{N}$ fertilizers are routinely used to supplement $\mathrm{N}$ from SOM and GM and to improve the synchrony of $\mathrm{N}$ release to meet crop demand. Organic $\mathrm{N}$ sources are more costly and more variable by nature than conventional $\mathrm{N}$ fertilizers, but an expanding knowledge base can assist growers with the most efficient type of management. Care in selecting $\mathrm{N}$ sources and the application practices for specific cropping situations will minimize problems associated with crop $\mathrm{N}$ deficiency or $\mathrm{N}$ losses that might contaminate surface or groundwater.

\section{Literature cited}

Agehara, S. and D.D. Warnacke. 2005. Soil moisture and temperature effects on nitrogen release from organic nitrogen sources. Soil Sci. Soc. Amer. J. 69:18441855 .

Aung, L.H. and G.J. Flick. 1980. The influence of fish solubles on growth and fruiting of tomato. HortScience 15:3233 .

Berry, P.M., R. Sylvester-Bradley, I. Philipps, D.J. Hatch, S.P. Cuttle, F.W. Rayns, and P. Gosling. 2002. Is the productivity of organic farms restricted by the supply of available nitrogen? Soil Use Mgt. 18: 248-255.

Buchanan, M. and S.R. Gliesmann. 1991. How compost fertilization affects soil nitrogen and crop yield. Biocycle 32:72-77.

Campbell, C.A., G.P. Lafrond, R.P. Zewnner, and Y.W. Jame. 1994. Nitrate leaching in a Udic Haploboroll as influenced by fertilization and legumes. J. Environ. Qual. 23:195-201.

Castellanos, J.Z. and P.F. Pratt. 1981. Mineralization of manure nitrogen correlation with laboratory indexes. Soil Sci. Soc. Amer. J. 45:3554-3557.

Cavero, J., R.E. Plant, C. Shennan, and D.B. Friedman. 1997. The effect of nitrogen source and crop rotation on the growth and yield of processing tomatoes. Nutrient Cycling Agroecosystems 47: 271-282.

Cherr, C.M., J.M.S. Scholberg, and R. McSorley. 2006. Green manure approaches to crop production: A synthesis. Agron. J. 98:302-319.

Cline, G.R. and A.F. Silvernail. 2002. Effects of cover crops, nitrogen, and tillage 
on sweet corn. HortTechnology 12:118125 .

Crews, T.E. and M.B. Peoples. 2005. Can the synchrony of nitrogen supply and crop demand be improved in legume and fertilizer-based agroecosystems? A review. Nutrient Cycling Agroecosystems 72:101-120.

Doran, J.W., M. Sarrantonio, and M.A. Liebig. 1996. Soil health and sustainability. Adv. Agron. 56:1-54.

Doran, J.W. and M.S. Smith. 1991. Overview: Role of cover crops in nitrogen cycling, p. 86-90. In: W.L. Hargrove (ed.). Cover crops for clean water. Soil Conservation Soc. Amer., Ankeny, IA.

Douglas, B.F. and F.R. Magdoff. 1991. An evaluation of nitrogen mineralization indices for organic residues. J. Environ. Qual. 20:368-372.

Fageria, N.K., V.C. Baligar, and B.A. Bailey. 2005. Role of cover crops in improving soil and row crop productivity. Commun. Soil Sci. Plant Anal. 36:27332757.

Flavel, T.C. and D.V. Murphy. 2006. Carbon and nitrogen mineralization rates after application of organic amendments to soil. J. Environ. Qual. 35:183193.

Gaskell, M. 2001. Yield of bell peppers and soil nitrate nitrogen following application of varying rates of compost or feather meal with and without a prior green manure. HortScience 36: 58. (Abstr.).

Gaskell, M. 2004. Nitrogen availability, supply, and sources in organic row crops. Proc. California Organic Production and Farming in the New Millennium: A Research Symposium. Berkeley, CA, 15 July 2004. University of California Sustainable Agr. Res. and Educ. Program, University of California, Davis. p. 13-20.

Gaskell, M., B. Fouche, S. Koike, T. Lanini, J. Mitchell, and R. Smith. 2000. Organic vegetable production in California-Science and practice. HortTechnology 10:699-713.

Gaskell, M., R. Smith, J. Mitchell, S.T. Koike, C. Fouche, T. Hartz, W. Horwath, and L. Jackson. 2006. Soil fertility management for organic crops. Univ. California Publ. 7249.

Griffin, T., M. Liebman, and J. Jemison, Jr. 2000. Cover crops for sweet corn production in a short season environment. Agron. J. 92:144-151.

Hadas, A. and M. Kautsky. 1994. Feather meal, a semi-slow release nitrogen fertilizer for organic farming. Fert. Res. 38:165-170.
Hadas, A., M. Kautsky, J. Goek, E.E. Kara, and M.C. Leirós. 2004. Rates of decomposition of plant residues and available nitrogen in soil, related to residue composition through simulation of carbon and nitrogen turnover. Soil Biol. Biochem. 36:255-266.

Hadas, A. and R. Rosenberg. 1992. Guano as a nitrogen source for fertigation in organic farming. Fert. Res. 31:209-214.

Hartz, T.K. 2002. Sustainable vegetable production in California: Current status, future prospects. HortScience 37:10151022.

Hartz, T.K. and P.R. Johnstone. 2006. Nitrogen availability from high-nitrogencontaining organic fertilizers. HortTechnology 16:39-42.

Hartz, T.K., J.P. Mitchell, and C. Giannini. 2000. Nitrogen and carbon mineralization dynamics of manures and composts. HortScience 35:209-212.

He, Z.L., D.V. Calvert, A.K. Alva, Y.C. Li, P.J. Stoffella, and D.J. Banks. 2003. Nitrogen transformation and ammonia volatilization from biosolids and compost applied to calcareous soil. Compost Sci. Util. 11:81-88.

Horwath, W.R. 2004. The importance of soil organic matter in the fertility of organic production systems. Proc. California Organic Production and Farming in the New Millennium: A Research Symposium. Berkeley, CA, 15 July 2004. Univ. of California Sustainable Agr. Res. and Educ. Program, Univ. of California, Davis. p. 8-12.

Horwath, W.R., O.C. Devêvre, T.A. Doane, A.W. Kramer, and C. van Kessel. 2002. Soil C sequestration management effects on $\mathrm{N}$ cycling and availability, $\mathrm{p}$. 155-164. In: J.M. Kimble, R. Lal, and R.F. Follett (eds.). Agricultural practices and policies for carbon sequestration in soil. Lewis Publishers, CRC Press, Boca Raton, FL.

Jackson, L.E. 2000. Fates and losses of nitrogen from a Nitrogen-15 labeled cover crop in an intensively managed vegetable system. Soil Sci. Soc. Amer. J. 64:1404-1412.

Jackson, L.E., L.J. Wyland, and L.J. Stivers. 1993. Winter cover crops to minimize nitrate losses in intensive lettuce production. J. Agr. Sci. 121:55-62.

Jarvis, S.C., E.A. Stockdale, M.A. Shepherd, and D.S. Powlson. 1996. Nitrogen mineralization in temperate agricultural soils: Processes and measurement. Adv. Agron. 57:187-237.

Kirchmann, H. 1989. A 3 year N balance study with aerobic, anaerobic and fresh
15 N-labelled poultry manure, p. 113125. In: J.A. Hansen and K. Henrikson (eds.). Nitrogen in organic wastes applied to soils. Academic Press, London.

Krusekopf, H.H., J.P. Mitchell, T.K. Hartz, D.M. May, E.M. Miyao, and M.D. Cahn. 2002. Pre sidedress soil nitrate testing identifies processing tomato fields not requiring sidedress $\mathrm{N}$ fertilizer. HortScience 37:520-524.

Kuo, S. and U.M. Sainju. 1998. Nitrogen mineralization and availability of mixed leguminous and non-leguminous cover crop residues in soil. Biol. Fertil. Soils 26:346-353.

Leirós, M.C. 1999. Dependence of mineralization of soil organic matter on temperature and moisture. Soil Biol. Biochem. 31:327-335.

Mikkelsen, R. 2000. Nutrient management for organic farming: A case study. J. Natural Resources Sci. Educ. 29:88-92.

Myers, R.J.K., C.A. Palm, E. Cuevas, I.U.N. Gunatilleke, and M. Brossard. 1994. The synchronization of nutrient mineralization and plant nutrient demand, p. 81-116. In: P.L. Woomer and M.J. Swift (eds.). The biological management of tropical soil fertility. Wiley-Sayce Publ., Chichester, UK.

Paul, E.A. and F.E. Clark. 1996. Soil microbiology and biochemistry. Academic Press, San Diego.

Poudel, D.D., W.R. Horwath, J.P. Mitchell, and S.R. Temple. 2001. Impacts of cropping systems on soil nitrogen storage and loss. Agr. Systems 68:253-268.

Robertson, G.P. 1997. Nitrogen use efficiency in row crop agriculture. Crop nitrogen use and soil nitrogen loss, p. 347-365. In: L.E. Jackson (ed.). Ecology in agriculture. Academic Press, New York.

Roe, N.E. and G.C. Cornforth. 2000. Effects of dairy lot scrapings and composted dairy manure on growth, yield, and profit potential of double cropped vegetables. Compost Sci. Util. 8:320327.

Russo, V.M. 2005. Organic vegetable transplant production. HortScience 40: 623-628.

Sarrantonio, M. and T.W. Scott. 1988. Tillage effects on availability of nitrogen to corn follow a winter green manure crop. Soil Sci. Soc. Amer. J. 52:16611668.

Scow, K.M. 1996. Soil microbial communities and carbon flow in agroecosystems, p. 367-412. In: L.E. Jackson (ed.). Ecology in agriculture. Academic Press, New York. 
Sharpley, A.N., S.C. Chapra, R. Wedepohl, J.T. Sims, T.C. Daniel, and K.R. Reddy. 1994. Managing agricultural phosphorus for the protection of surface waters: Issues and options. J. Environ. Qual. 23:437-451.

Shennan, C. 1992. Cover crops, nitrogen cycling and soil properties in semi-arid irrigated vegetable production systems. HortScience 27:749-754.

Silgram, M. and M.A. Shepherd. 1999. The effects of cultivation on soil nitrogen mineralization. Adv. Agron. 65:267-311.

Smil, V. 1999. Nitrogen in crop production: An account of global flows. Global Biogeochem. Cycles 13:647-662.

Smith, R.F. 2001. Organic fertilizer trial on broccoli. Central Coast Family Farm Report. Univ. of California Coop. Ext., Salinas.

Stevenson, F.J. 1994. Humus chemistry: Genesis, composition, reactions. 2nd ed. Wiley, Hoboken, NJ.

Stockdale, E.A., M.A. Shepherd, S. Fortune, and S.P. Cuttle. 2002. Soil fertility in organic farming systems-Fundamentally different? Soil Use Mgt. 18:301308.

Sullivan, D.M., J.M. Hart, and N.W. Christensen. 1999. Nitrogen uptake and utilization by Pacific Northwest crops. Oregon State Univ. Ext. Serv. PNW 513.

Temple, S.R., D.B. Friedman, O. Somasco, H. Ferris, K. Scow, and K. Klonsky. 1994. An interdisciplinary experiment station based participatory comparison of alternative crop management systems for California's Sacramento Valley. Amer. J. Alternative Agr. 9:6471 .

Thönnissen, C., J.K. Midmore, R.J. Holmer, and U. Schmidhalter. 2000. Tomato crop response to short-duration legume green manures in tropical vegetable systems. Agron. J. 92:245253.

Tourte, L., M. Buchanan, K. Klonsky, and D. Mountjoy. 2003. Estimated costs of potential benefits for an annually planted cover crop. University of California Coop. Ext., Watsonville.
Tyson, S.C. and M.L. Cabrera. 1993. Nitrogen mineralization in soils amended with composted and uncomposted poultry manure. Comm. Soil Sci. Plant Analysis 24:2361-2374.

U.S. Department of Agriculture. 2007. The National Organic Program. Production and handling-Regulatory text. 14 June 2007. <http://www.ams.usda. gov/nop/NOP/standards/ProdHand Reg.html>.

Wagger, M.G. 1989. Cover crop management and nitrogen rate in relation to growth and yield of no-till corn. Agron. J. 81:533-538.

Watson, C.A., D. Atkinson, P. Gosling, L.R. Jackson, and F.W. Rayns. 2002. Managing soil fertility in organic farming systems. Soil Use Mgt. 18:239-247.

Wyland, L.J., L.E. Jackson, W.E. Chaney, K. Klonsky, S.T. Koike, and B. Kimple. 1996. Altering surface soil dynamics with cover crops in a vegetable cropping system: Impacts on yield nitrate leaching, pests and management costs. Agr. Ecosystems Environ. 59:1-17. 